\title{
Social Media and Visit Decision to Tourist Destinations: Measuring the Impact of Instagram on Expatriates in Indonesia
}

\author{
ILHAM PRISGUNANTO \\ Police Science College, Indonesia
}

\begin{abstract}
The Indonesian government has huge interests in increasing the number of tourists visiting Indonesia. Social media have been argued to have significant roles in influencing people to visit tourist destinations. Based on the uses and gratification perspective, this study aims to examine whether social media, especially Instagram, influence people, especially expatriates, in deciding to visit tourist destinations in Indonesia. The respondents were 100 foreigners or expatriate workers who live in Indonesia, particularly in Tangerang Selatan regency. The questionnaires were distributed among the sample from August to November 2018. The hypothesis was tested using a simple linear regression method. For the analysis, this study has applied a semantic differential scale. This study concludes that the influence of Instagram to the foreign workers' decision to visit tourist destinations in Indonesia is indeed very small, only $11.2 \%$. Instagram, for most netizens, is used not only to seek information regarding tourism services and facilities but more importantly to build relationships among netizens. The shared information will not be fully trusted by netizens, but would rather be assessed and evaluated by first looking at the reputation of the person who provides the information. This study also finds that information sharing on Instagram is not correlated necessarily to the netizens' attitudes and behaviors, particularly towards their desires to visit Indonesian destinations. However, social media are used as a reference for the future visit.
\end{abstract}

Keywords: Social media, tourist visit decisions, uses and gratification, Instagram, expatriate workers.

\section{INTRODUCTION}

The industry 4.0 era of information technology in contemporary society is signified by the wider use of social media networking. This 4.0 era posits information as something very important in human life (Prisgunanto, 2016, p. 114). The use of smartphones has now enabled people to access social media anytime and anywhere at a very cheap price. Nowadays, mostly every information is open and free, while people have the freedom to access and produce information. Everything is now open and can be freely accessed (Dutton et al., 2011). In general, we may refer to this phenomenon as the democratization of information.

The extensive use of social media has therefore changed people's behaviours and interactions with each other in their lives. Netizens share all kinds of information and optimize a different kind of social media as their major personal reference. They can do various activities independently, while many works can also be simplified and combined through the use of social media. Another important new feature of social media is how messages are getting attention and responses quickly. Generally, netizens believe that that information available in social media as objective and trustworthy. Interestingly, it is also obvious in many cases that social media are widely used as a source of information for decision making and problem-solving.

The strong influence of social media in contemporary society has led the government sectors to optimize these new media in campaigning and promoting their programmes to the citizens. This is very obvious when we observe the tourism promotion of Indonesian 
destinations through social media. Nowadays, the tourism industry in Indonesia is booming, both in the international and domestic markets. The Indonesian government has been trying to increase the number of tourists in many ways in order to contribute to the Indonesian economic income. Moreover, the Indonesian government has supported the tourism industry to be the main development sector and national flagship program. In this context, social media are argued to have important roles in promoting tourist destinations and influencing tourists to visit promoted destinations. Instagram, as one of the social media platforms that have capabilities to feature images, videos, and sounds, is perceived as a very important medium in attracting people to visit certain displayed destinations. Therefore, Instagram has played a significant role in developing the tourism industry in Indonesia. This phenomenon has justified the concept of "content is really a king". In the cyber digital era, the power of information or content has become a very important feature in the world of tourism. Then, in this context, the term WIIFM (what's in it for me) should be clearly mentioned in any marketing and promotional content to ensure that the messages will be delivered effectively (Medina, Sanchez-Tabernero \& Arrese, 2016).

This study applies the uses and gratification approach, which prioritizes content, interaction, and media use rather than other factors, such as the use of software or social media regulatory systems. In this approach that was developed for analyzing persons' use of media, the question of what 'mass media do to persons' does not matter but the question of what 'persons do with media' does. This approach perceives individuals as active audiences who use media in order to gain specific motivations and satisfy their specific needs (Tarakci \& Yenicikt.

This study perceives that to some extent social media influences people's decisions in visiting tourist destinations. However, this thesis should be carefully examined and measured. Thus, this study aims to examine whether social media influence expatriate's motivation, desire, as well as the decision to visit tourist destinations that are promoted in such social media. This study would take the expatriates in Indonesia as research respondents, trying to relate social media exposure, especially Instagram, their motivation and decision of visiting tourist destinations, and security issues.

\section{LITERATURE REVIEW}

Many previous researchers within tourism studies that discussed social media aspects have paid more attention to interpersonal communication, especially from the perspective of marketing communication or integrated marketing communication (IMC). These studies usually have strong practical motivations, such as how to increase the number of visits, how to do segmentation of visitors, or how to understand consumer behaviour (Zivkovic, Gajic \& Brdar, 2014). Another topic is about the content reproductions, consumer networks and new media expansion which are closely associated with the existence of funding and the political economy of media (Medina, Sanchez-Tabernero \& Arrese, 2016). Other studies have discussed the online word of mouth (eWorm) to evaluate the influences of social media in the tourism industry, especially in consumers' personal behaviour of buying decisions. They also discussed the issues of ethics and positive responses coming from the local communities, including hospitalities issues (Singh \& Duhan, 2016). 
This research will examine the hierarchical effect of the influence of social media content on human behaviour. For the sake of analysis, this research generally considers the content of social media to be similar to the content of mainstream mass media. Thus, this study would apply uses and gratification theory which were more popular as a tool to analyse mainstream mass media influence.

The uses and gratification theory looks at the levels of viewers' attitudes towards media exposure, which could be divided into three levels, namely cognitive, affective and conative. It comes from McGuire's psychological motives for media use. His sixteen-cell classification scheme for human motives highlights the relevance of a large number of psychological theories for understanding the cognitive and affective underpinnings of media consumption (Rosengren, Wenner and Palmgreen, 1985, p. 21). At the cognitive level, the influences of mass media lay on the audience's mind only. At the affective level, the influence of media exposure occurs at a deeper level where the feelings and desires of the audience are affected deeply. At the conative level, the effectiveness of mass media occurs at the level of action and the audience's active behaviour towards mass media content. This hierarchical model is used in order to explore the influence level of Instagram in affecting the foreign worker's desires and behaviours to visit tourist destinations in Indonesia.

Rosengren, Wenner, and Palmgreen (1985) have also distinguished three perspectives of media influence, namely macro, messo and micro paradigms. The macro paradigm views mass media as powerful agencies, particularly in directing human behaviours and desires towards something. The messo paradigm considers the place of mass media is in the middle, both influencing or not, depending on the contexts or certain situations and conditions. Whereas the micro paradigm views mass media as not having direct influences on the audience, it depends on the previous psychological experiences to perceive and interpret mass media messages.

\section{METHODOLOGY}

Based on a micro perspective of mass media influence, this study assumes that mass media has no direct influences on the audiences. Based on the social dramaturgy perspective (Goffman, 1956), two stages should be taken into account in order to examine social media from the user side, namely the category of information sharing and relationship building. This would allow the study to represent the social dimensions of social media users, particularly through interactions between humans as citizens (Kaplan \& Haenlein, 2010). For these reasons, the independent variables in this study are these two factors, i.e. information sharing and relation-building, in order to find out the most dominant element of the netizens interaction with social media. The use of the two factors also refers to the previous research on the changing of behaviours and social media (O'Adewuyi \& Adefem, 2016). The information-sharing element has been applied in the research on behavioural changes (Miguen, Costa \& Baggio, 2008). While the dependent variable of this study is the hierarchical effect of mass media use, based on the uses and gratification theory.

The respondents of this research were expatriates who live in Indonesia, particularly in Pamulang Sub-district, Tangerang Selatan District. Their opinions regarding Instagram and tourism destinations in Indonesia were carefully collected and then analysed. The number of respondents was 100 persons. The questionnaires were distributed during the period of four months, from August to November 2018. It was selected because the posts and discussions about Indonesian tourism destinations increasingly appeared on Instagram in that period. 
This study has collected quantitative data and has also quantitatively analysed the data. The study has applied simple linear regression statistics. For measurements, a semantic differential scale was applied. This study has also considered the spread of economic living among expatriate workers in Indonesia, which is closely related to their perceptions and understanding of the popular tourist destinations in Indonesia. Their choices to visit certain places were highly taken into account, by considering the level of comfort and security when they visit the places.

\section{RESULT AND DISCUSSION}

This research has applied quantitative data processing. The first step was conducting the testing of data quality, using reliability measurements and internal validity. The reliability test has applied Cronbach Alpha. The hypothesis was as follow:

a. $\mathrm{HO}=$ Cronbach Alpha values - if under $r$ Table $(0,361)$ therefore it is unreliable

b. $H 1=$ Cronbach Alpha values - if under $r$ Table $(0,361)$ therefore it is reliable.

Table 1: Reliability and validity test

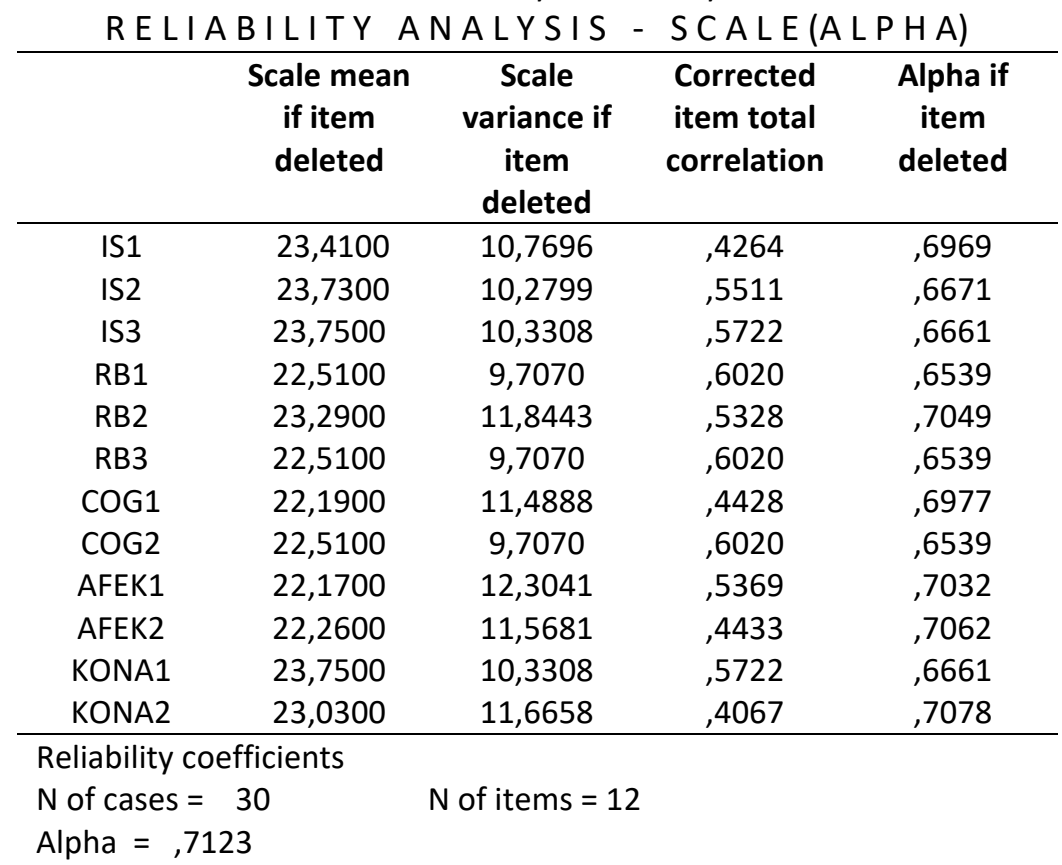

Table 1 shows that if Cronbach Alpha is 0,7123 , therefore the test belongs to $\mathrm{H} 1$ with $\mathrm{HO}$ refusal. It means that data were reliable. The reliability test was used to check if respondents' answers towards research instruments are reliable. In survey-based research, the respondents' true and definite answers are significant in order to enable the research to find the reliability of data, which are needed to be measured.

\section{Validity Test}

This research by using 30 samples, the value $r$-table $\mathrm{df}(30,2)$ is 0,361 . Therefore, the variable instrument is tested if it is under it's r-table.

$\mathrm{HO}=\mathrm{r}$ value measuring each variable $<r$ Table $(0,361)$

$\mathrm{H} 1=\mathrm{r}$ value measuring each variable $>r$ Table $(0,361)$ 
a. IS1 (Information Sharing) variable $r=, 4264$ the score is $>0.361$ then the variable is being on $\mathrm{H} 1$ area with rejection $\mathrm{HO}$.

b. IS2 (Information Sharing) variable $r=, 5511$ the score is $>0.361$ then the variable is being on $\mathrm{H} 1$ area with rejection $\mathrm{HO}$.

c. IS3 (Information Sharing) variable $r=, 5722$ the score is $>0.361$ then the variable is being on $\mathrm{H} 1$ area with rejection $\mathrm{HO}$.

d. RB1 (Relation Building) variable $r=, 6020$ the score is $>0.361$ then the variable is being on $\mathrm{H} 1$ area with rejection $\mathrm{HO}$.

e. RB2 (Relation Building) variable $r=, 5328$ the score is $>0.361$ then the variable is being on $\mathrm{H} 1$ area with rejection $\mathrm{HO}$.

f. COG1 (Cognitive) variable $r=, 4428$ the score is $>0.361$ then the variable is being on $\mathrm{H} 1$ area with rejection $\mathrm{HO}$.

g. COG2 (Cognitive) variable $r=, 6020$ the score is $>0.361$ then the variable is being on $\mathrm{H} 1$ area with rejection $\mathrm{H} 0$.

h. AFEK1 (Affective) variable $r=, 5369$ the score is $>0.361$ then the variable is being on $\mathrm{H} 1$ area with rejection $\mathrm{HO}$.

i. AFEK2 (Affective) variable $r=, 4433$ the score is $>0.361$ then the variable is being on $\mathrm{H} 1$ area with rejection $\mathrm{HO}$.

j. KONA1 (Conative) variable $r=, 5722$ the score is $>0.361$ then the variable is being on $\mathrm{H} 1$ area with rejection $\mathrm{HO}$.

k. KONA2 (Conative) variable $r=, 4067$ the score is $>0.361$ then the variable is being on $\mathrm{H} 1$ area with rejection $\mathrm{HO}$.

From the above data, it is clear that the value and validity of the questions have met the requirements. It shows all variables are above the table value $(0,361$ wit $\mathrm{df}$. 28 , sample number 30 respondents). The accuracy of the answers shows that the instrument of this research can be used. The data error level is also small before further hypothesis examination conducted.

\section{Demographic Background}

In this section, I would describe and illustrate the backgrounds of the respondents in order to reveal their characteristics. The descriptive data would be explained into a number of categories, such as gender, age, marriage status, as well as the number of Instagram accounts they have.

Table 2: Gender aspect of the respondent

\begin{tabular}{llcccc}
\hline & & Frequency & Percent & Valid Percent & Cumulative Percent \\
\hline Valid & Man & 37 & 37.0 & 37.0 & 37.0 \\
& Women & 63 & 63.0 & 63.0 & 100.0 \\
& Total & $\mathbf{1 0 0}$ & $\mathbf{1 0 0 . 0}$ & $\mathbf{1 0 0 . 0}$ & \\
\hline
\end{tabular}

Table 2 shows that the majority of respondents who answered the survey are female (63 respondents, or 63\%). The number of male respondents is $37 \%$. Clearly, the survey is dominated by the perspectives of female respondents. The female respondents answer the questions with their specific tastes and emotions. This finding shows that social media users are indeed dominated by a female rather than male expatriates. The issues of security and comfort when traveling are the two most important elements to consider when they plan a 
Social Media and Visit Decision to Tourist Destinations: Measuring the Impact of Instagram on Expatriates in Indonesia

Ilham Prisgunanto

visit. This study shows that female respondents are more sensitive and considerate than their male counterparts.

Table 3: The origin of country of the respondent

\begin{tabular}{llcccc}
\hline & & Frequency & Percent & Valid Percent & Cumulative Percent \\
\hline Valid & Australia & 13 & 13.0 & 13.0 & 13.0 \\
& Singapore & 15 & 15.0 & 15.0 & 28.0 \\
& Malaysian & 33 & 33.0 & 33.0 & 61.0 \\
USA & 3 & 3.0 & 3.0 & 64.0 \\
UK & 6 & 6.0 & 6.0 & 70.0 \\
Russia & 6 & 6.0 & 6.0 & 76.0 \\
& Other & 24 & 24.0 & 24.0 & 100.0 \\
& Total & $\mathbf{1 0 0}$ & $\mathbf{1 0 0 . 0}$ & $\mathbf{1 0 0 . 0}$ & \\
\hline
\end{tabular}

Table 3 shows that most of the respondents are expatriates from Malaysia ( 33 individuals or 33\%). There are 15 respondents from Singapore (15\%), and 13 respondents from Australia (13\%). The British and Russian respondents each are 6 persons (6\%), and Americans are 3 persons (3\%). There are also respondents from other countries (24\%), such as from China, France, and others.

The data show that most of the respondents are from Malaysia, working in a different type of jobs and projects in Indonesia. Those who are from Indonesia' neighbouring countries usually have a better understanding of Indonesia, compared to those who are not. The Singaporean expatriates in Indonesia for instance, due to the closeness, they normally have more opportunities to work or visit Indonesia. Cultural similarities between Indonesia and their neighbours are significant elements that influence their good understanding of the complexity of Indonesia through widely available information on the Internet, including information about tourist destinations.

Table 4: Range of age of the respondent

\begin{tabular}{llcccc}
\hline & & Frequency & Percent & Valid Percent & Cumulative Percent \\
\hline Valid & $<21$ & 2 & 2.0 & 2.0 & 2.0 \\
& $22-30$ & 2 & 2.0 & 2.0 & 4.0 \\
& $31-40$ & 44 & 44.0 & 44.0 & 48.0 \\
& $>41$ & 52 & 52.0 & 52.0 & 100.0 \\
& Total & 100 & $\mathbf{1 0 0 . 0}$ & $\mathbf{1 0 0 . 0}$ & \\
\hline
\end{tabular}

Table 4 shows that a large number of survey questions are answered by people aged over 41 (52\%). The second largest group is people aged between 31 and 40 (44\%). Those aged between 22 and 30, and under 21, are the lowest one (2\%).

The Instagram users in this survey are dominated by the adult groups who have more adequate sources of income. It can be understood why most of the respondents are from the older group. The source of income plays a significant role in decision making to select and visit tourist destinations in Indonesia. This particular fact is important because it shows that the use of Instagram as social media is popular among these adult groups. When Instagram users are coming from an older group, there is a tendency to carefully filter the information before sharing it. Older users have a tendency to take time to think first before sharing certain content with their circle of friends and networks. The experiences and wider networking of the older users have also played significant roles. It is somehow different from the general 
attitudes of youth or teenage users.

Table 5: Family status of the respondent

\begin{tabular}{llcccc}
\hline & & Frequency & Percent & Valid Percent & Cumulative Percent \\
\hline Valid & Married & 78 & 78.0 & 78.0 & 78.0 \\
& Single & 22 & 22.0 & 22.0 & 100.0 \\
& Total & 100 & $\mathbf{1 0 0 . 0}$ & $\mathbf{1 0 0 . 0}$ & \\
\hline
\end{tabular}

Table 5 shows the marriage status of the respondents. Most of them are married (78 persons or $78 \%)$. The rest (22\%) answered the survey as being single. The marriage status and some families have also influenced their decisions differently, for instance regarding the type of accommodations and suitable itineraries for family-oriented traveling. The specific and complex needs to travel with family are an important factor behind someone's decision to visit certain tourist destinations. Married respondents usually travel with their families. It can be argued that their decisions are motivated by the collectivistic needs and interests rather than an individual. When they are happy with the experience of a tourist destination in Indonesia, they normally would share the experiences and information with their extended family and close networks or friends.

Table 6: Instagram account of the respondent

\begin{tabular}{llcccc}
\hline & & Frequency & Percent & Valid Percent & Cumulative Percent \\
\hline \multirow{4}{*}{ Valid } & only one account & 80 & 80.0 & 80.0 & 80.0 \\
& 2 account & 16 & 16.0 & 16.0 & 96.0 \\
& $>3$ account & 4 & 4.0 & 4.0 & 100.0 \\
& Total & $\mathbf{1 0 0}$ & $\mathbf{1 0 0 . 0}$ & $\mathbf{1 0 0 . 0}$ & \\
\hline
\end{tabular}

Table 6 shows the number of Instagram accounts each respondent has. The number of respondents having a single account is 80 persons or $80 \%$. This shows that the respondents tend to use their real identities on Instagram. There are 16 respondents (16\%) who have 2 accounts, and those who have 3 or more Instagram accounts are only 4 persons (4\%). The use of social media is closely connected to their level of trust in the information displayed on social media. The survey shows to what extent someone has trusted the information. Having only a single account shows that there is no intention to hide real identities or to emerge the fake identities. It also means that on one side the user trusts the medium as well as its content, and on another side, they want to be trusted and receive trusted information. In contrast, it is suspected that someone who has more than one social media account shows that he is trying to hide his identity from others (Safko, 2010, p. 4).

\section{Social Media Analysis}

Table 7 shows two variables used in this survey, namely information sharing and relationbuilding from the user point of view. Of the two factors, the mean of information sharing $(2,42)$ and the mean of relation-building $(1,62)$ can be explained. Netizens seem to prefer to share information rather than to build new relationships in social media. 
Table 7: Analysis of social media

\begin{tabular}{llcc}
\hline & & INFSHARE & RELBUILD \\
\hline $\mathrm{N}$ & Valid & 100 & 100 \\
& Missing & 0 & 0 \\
Mean & & $\mathbf{2 , 4 2 0 0}$ & $\mathbf{1 , 6 2 0 0}$ \\
\hline
\end{tabular}

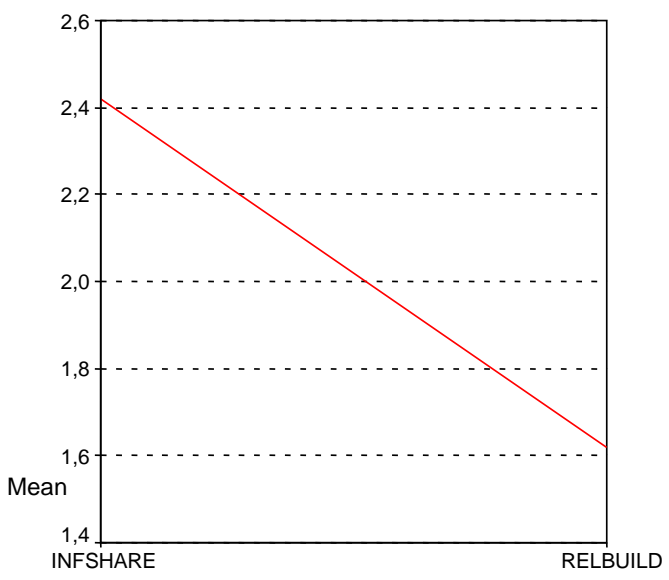

Figure 1: Social media variable

Therefore, this finding confirms the argument that social media is closely connected with the aspects of information sharing. This research shows that social media is particularly used to share information than for other purposes. Social media are tools to share information. But, people also use social media to connect with other people. In addition, social media are not just tools to connect with other people, but also to create new relationships with one another. The reliability of the social media is not only one-way and two-party communication such as telephone, fax, radio, billboards, but in many people and complex relations (Safko, 2010, p. 4).

\section{Netizens' Behavioural Analysis}

Table 8 shows the factors which are influencing netizens' behaviours in Instagram use. The cognitive mean is 2,66 , the effective mean is 1,58 , and the conative mean is 1,25 . In the mass media effect hierarchy, as mentioned beforehand, we could stratify the influence of media exposure to the cognitive, affective and conative. The statistic already shows the achievement level of social media exposure in this hierarchy. It shows that contents in social media influence the users mostly in the cognitive level only. It could be argued that motivation to visit a tourist destination influenced by Instagram's contents is in the stage of cognitive.

Table 8: Behavioural analysis of the respondent

\begin{tabular}{llccc}
\hline & & Cognitive & Affective & Conative \\
\hline $\mathrm{N}$ & Valid & 100 & 100 & 100 \\
& Missing & 0 & 0 & 0 \\
Mean & & $\mathbf{2 , 6 6 0 0}$ & $\mathbf{1 , 5 8 0 0}$ & $\mathbf{1 , 2 5 0 0}$ \\
\hline
\end{tabular}




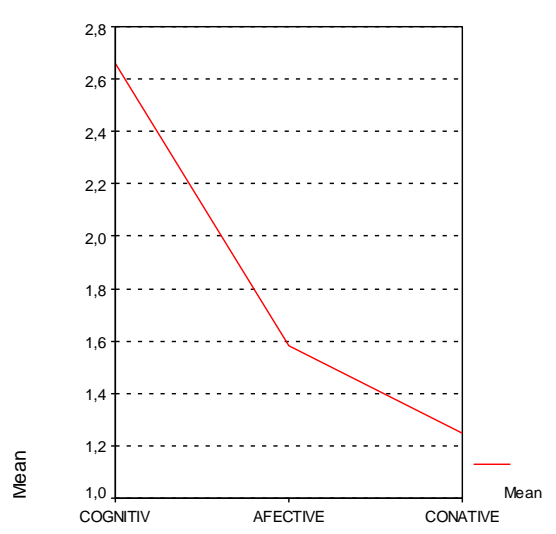

Figure 2: Behavioural analysis

\section{Hypothesis Examination}

Table 9 shows that the correlation examination between social media variables (information sharing and relation building) with tourists' behaviour, seen as follows:

a. Information sharing correlations with value behaviours, $p$ value $0,233>0,05$ (onetailed) therefore it belongs to $\mathrm{HO}$ area $\mathrm{H} 1$ refusal. There are no correlations between information sharing and behaviour.

b. Relation building correlations with behaviours, $p$ value $0,000<0,05$ (one tailed) therefore it belongs to $\mathrm{H} 1$ area with $\mathrm{HO}$ refusal. There are correlations between relation building with behaviour namely $r=0,345$.

Table 9: Correlations analysis

\begin{tabular}{lcccc}
\hline & & BEHAVIOUR & INFSHARE & RELBUILD \\
\hline Pearson & BEHAVIOUR & 1,000 &, 074 &, 345 \\
Correlation & INFSHARE &, 074 & 1,000 &,- 087 \\
& RELBUILD &, 345 &,- 087 & 1,000 \\
Sig. (1-tailed) & BEHAVIOUR & $\cdot$ &, 233 &, 000 \\
& INFSHARE &, 233 &. &, 194 \\
& RELBUILD &, 000 &, 194 &. \\
$\mathrm{~N}$ & BEHAVIOUR & 100 & 100 & 100 \\
& INFSHARE & 100 & 100 & 100 \\
& RELBUILD & 100 & 100 & 100 \\
\hline
\end{tabular}

Table 10: Model summary

\begin{tabular}{lccccc}
\hline Model & $\mathbf{R}$ & R Square & $\begin{array}{l}\text { Adjusted } \\
\text { R Square }\end{array}$ & $\begin{array}{c}\text { Std. Error of } \\
\text { the Estimate }\end{array}$ & Durbin-Watson \\
\hline 1 &, $074(\mathrm{a})$ &, 005 &,- 005 &, 35597 & \\
2 &, $360(\mathrm{~b})$ &, 130 &, 112 &, 33466 & 1,077 \\
\hline \multicolumn{7}{c}{ a Predictors: (Constant), INFSHARE } & & \\
& b Predictors: (Constant), INFSHARE, RELBUILD & \\
& Dependent variable: BEHAVIOUR
\end{tabular}

The model summary in Table 10 shows the information sharing $r$ (adjusted $R$ Square) $=-0,005$, while information sharing value and relation building, simultaneously $r$ (adjusted $R$ Square) $=0,112$. Therefore, the influence to contribute is $11,2 \%$, while $88,8 \%$ by other factors. 
Social Media and Visit Decision to Tourist Destinations: Measuring the Impact of Instagram on Expatriates in Indonesia

Table 11: Level of difference - ANOVA(c)

\begin{tabular}{lllcccc}
\hline Model & & $\begin{array}{c}\text { Sum of } \\
\text { Squares }\end{array}$ & df & Mean Square & F & Sig. \\
\hline 1 & Regression &, 068 & 1 &, 068 &, 536 &, $466(\mathrm{a})$ \\
& Residual & 12,418 & 98 &, 127 & & \\
& Total & 12,486 & 99 & & & \\
2 & Regression & 1,622 & 2 &, 811 & 7,243 &, $001(\mathrm{~b})$ \\
& Residual & 10,864 & 97 &, 112 & & \\
& Total & 12,486 & 99 & & & \\
\end{tabular}

a Predictors: (Constant), INFSHARE

b Predictors: (Constant), INFSHARE, RELBUILD

c Dependent variable: BEHAVIOUR

Table 11 shows the differences of behaviours before and after using social media by the respondents as follows:

a. Information sharing Anova value, $p$ value 0,466 means under average 0,05 $(>0,05)$. Therefore, it can be said, the acceptance $\mathrm{HO}$ and the rejection $\mathrm{HA}$. There are no behavioural differences of people to visit a tourist destination after content checking in social media.

b. Relation building Anova value, $p$ value 0,001 is under $0,05(<0,05)$. Therefore, it can be said $\mathrm{HA}$ acceptance and $\mathrm{HO}$ rejection. There is a change of behaviour and attitudes of people to visit a tourist destination after checking the content of social media.

Table 11 shows that the variable of information sharing is not different before or after using Instagram. Individually, the element of sharing information cannot be argued to be changed just because of social media use. However, it is different from the relation-building variable, which is changed due to the nature of social media contents. It is clear that there is an indication of the changing influence of relation building towards the attitudes after using Instagram. The change in attitude more or less will contribute to the open possibilities of using social media. In this step, it is clear that many elements of information are eliminated and then falling as one of a strong factor in utilizing social media in order to change their behaviours in selecting tourist destinations.

Table 12: Regression equation - Coefficients(a)

\begin{tabular}{|c|c|c|c|c|c|c|c|c|c|c|c|}
\hline \multirow[t]{2}{*}{$\begin{array}{l}\text { Mo } \\
\text { del }\end{array}$} & & $\begin{array}{r}\text { Unsta } \\
\text { coef }\end{array}$ & $\begin{array}{l}\text { dardized } \\
\text { cients }\end{array}$ & $\begin{array}{l}\text { Standar } \\
\text { dized } \\
\text { coeffici } \\
\text { ents }\end{array}$ & $\mathbf{t}$ & Sig. & \multicolumn{3}{|c|}{ Correlations } & \multicolumn{2}{|c|}{$\begin{array}{c}\text { Co-linearity } \\
\text { statistics }\end{array}$} \\
\hline & & B & $\begin{array}{l}\text { Std. } \\
\text { Error }\end{array}$ & Beta & & & $\begin{array}{l}\text { Zero- } \\
\text { order }\end{array}$ & Partial & Part & $\begin{array}{l}\text { Toler } \\
\text { ance }\end{array}$ & VIF \\
\hline \multirow[t]{5}{*}{1} & (Constant) & 1,826 & ,080 & & $\begin{array}{c}22,71 \\
3\end{array}$ & 0,00 & & & & & \\
\hline & INFSHARE & ,023 & ,031 & ,074 & ,732 & ,466 & ,074 & ,074 & 074 & 1,000 & 1,000 \\
\hline & (Constant) & 1,321 & 155 & & 8,514 & ,000 & & & & & \\
\hline & INFSHARE & ,033 & ,030 & 105 & 1,101 & 274 & ,074 & 111 & 104 & 992 & 1,008 \\
\hline & RELBUILD & ,286 & ,077 & ,354 & 3,725 & ,000 & ,345 & ,354 & ,353 & 992 & 1,008 \\
\hline
\end{tabular}

a Dependent variable: BEHAVIOUR 
Table 12 shows the equation that can be used in this research to predict the possibilities of netizens to use Instagram:

a. Information share $p$ value 0,274 is above average $0,05(>0,05)$. Therefore it is known the acceptance of $\mathrm{HO}$ with the $\mathrm{HA}$ rejection. This factor cannot be included to predict the increasing level of netizens to visit a tourist destination.

b. Relation building $p$ value 0,000 is under $0,05(<0,05)$. Therefore the acceptance of $\mathrm{HA}$ with $\mathrm{HO}$ rejection. It can be said that this factor can be included to predict the increasing level of netizens' behaviour to visit a tourist destination.

Thus, it can be concluded that the equation to predict the use of social media towards a tourist destination is:

$$
Y=1,321+0,354 X_{2 \text { (Relation Building) }}
$$

Therefore, it is clear that information sharing factors in utilizing social media by expatriates in Indonesia cannot be used and formulated with the behavioural changes towards the decision to choose a tourist destination. The formulation can only be predicted at the relations building levels in certain social dimensions.

\section{DISCUSSION}

The research shows that social media has influenced expatriate actions and behaviours to visit tourist destinations in Indonesia. However, the level of influence is actually quite low, only $11,2 \%$. It is clear that images, videos or texts about Indonesian tourist destinations on Instagram not necessarily give positive contributions to the netizens' behavioural changes, particularly among the expatriates in regard to their desires to visit Indonesian destinations. It is not proven that excessive contents make social media are able to change the attitudes and one's judgement towards tourist destinations in Indonesia.

Most of the tourists from gen $Z$ says they would not rely on social media when planning and making their decision (Rathony, 2013). This research confirms that prospective tourists would take advice from their close networks rather than from social media (see also Shyle \& Hysi, 2015). Furthermore, this study also confirms the idea that social media do not really give an impact on the decision of the next visit. Thus, this study has justified the argument of micro mass media theory that mass media actually have no direct significant influences on people. Mass media only make them think about what they have in their minds and to be talking about. Lippmann has argued that the media act as the mediator between the world outside and the pictures in our heads (Griffin, 2009, p. 359).

This study also confirms that social media are used by the older netizens to play a role in the cognitive phase (Quinn, 2018). In the hierarchical level of social media influence, this study concludes that social media contents only influence people at the cognitive phase, and not at the conative phase. It can be said that social media content is not taken seriously by netizens to decide their future tourist visits. Therefore, the negative images, which are campaigned around tourism destinations, should not be regarded as something very serious. The netizens' negative perceptions of the destinations would stay only in their mind, not automatically have the capacities to change their behaviour and attitudes toward the destinations. Even when the negative pictures in social media related to the security issues, it will stay only in the cognitive phase. 
This research shows that netizens use Instagram as a source of information of the tourist destinations for their future visits. But, it is not the main goal of tourists to share and get tourist information. Yet, social media are tools to interact and build a relationship. The main reason for netizens of using Instagram is actually in this potential of 'relationship building' other than other reasons. Socializing role is one of the primary reasons believed by most people in using social networking sites, including Instagram (Ting et al., 2015, p. 23). Instagram users are mainly motivated by social interaction (Casal, Havian \& Ibanez-Sancez, 2017). Based on the research findings, it is clear that the interest to relate or interact with others is the most important motivation, especially with specific ethics and rules in their social interactions and use of social media. Social media are indeed used to select and filter new friendships for the future.

With this relationship-building factor, it is difficult to convince and influence people, unless they are becoming an internal part of the social circles in social media. The findings of this study show that the information from social media is not fully trusted by the netizens, but the social media content will only be used as a reference or additional information by netizens to shape their attitude towards tourist destinations. The truth of the information displayed in social media will be objectively assessed by the community in its own netizens circles. The available information will be assessed gradually, by first looking at the reputation and profile of the person who provides the information. From the internal circle and deeper relations, the information will be shared and the level of trust becomes stronger among the netizens who are already establishing strong relations. Then, it will influence new people to trust the contents of these social media circles.

\section{CONCLUSION}

As a very popular social media, Instagram has a strong potential to influence expatriate desires to visit tourist destinations in the Indonesian archipelago. However, this research found that the level of Instagram influence to their users is actually quite low, it is only $11,2 \%$. This research concluded that contents in Instagram not necessarily give positive contributions to the desire and decision to visit Indonesian tourist destinations, particularly among the expatriates. The information sharing factor in Instagram is not correlated necessarily to the expatriate attitudes and behaviours, particularly towards their desires to visit Indonesian destinations.

This study has justified the argument of micro mass media theory that mass media actually have no direct influences on people. Further, this study concluded that social media contents only influence users at the cognitive phase, and not at the conative phase. In this case, the negative images of certain destinations in social media, even if it relates to the security issues, will stay only in the cognitive phase. Social media content is not taken seriously by netizens. Therefore, negative issues from social media should not be overly and seriously responded by the state, especially regarding tourism issues. In this notion, the truth of information will be assessed by the community in its own netizens circles, especially by looking at the reputation of the person who provides the information.

This study also concluded that Instagram is widely used for building social relations. The main use of social media among expatriates is to build relationships, to connect and interact intensively between expatriate netizens. It implies for netizens in general that the information in social media is not directly accepted, but the information would be justified 
through certain circles or relationships. It should be a very important recommendation for the tour operators, travelling agencies, tourist destinations management, as well as government bodies who deal with tourism activities to increase the number of tourist visits, namely build strong and deep relationships with their prospective tourists. While, for the next study, it is very important to examine the level of trust towards tourism information available in social media, what kind of factors influence the trust, and how it is developed through and in social media.

\section{BIODATA}

Ilham Prisgunanto is a senior lecturer at the Police Science College, Indonesia. Email: prisgunanto@gmail.com 


\section{REFERENCES}

Casal L. O., Havian, C., \& Ibanez-Sanchez, S. (2017). Understanding consumer interaction on Instagram: The role of satisfaction, hedonism, and content characteristic. Journal of Cyber Psychology, Behaviour and Social Networking, 20(6), 369-375.

Dutton, W. H., Dopatka, A., Law, G., \& Nash, V. (2011). Freedom of connection, freedom of expression: Changing legal and regulatory ecology shaping the Internet. Paris: United Nations Educational, Science and Cultural Organization.

Goffman, E. (1956). The presentation of self in everyday life. New York: Doubleday.

Griffin, E. M. (2009). A first look at communication theory (7th ed.) Boston: McGraw Hill.

Kaplan, A., \& Haenlein, M. (2010). Users of the world, unite! The challenges and opportunities of social media. Journal of Business Horizons, 53(1), 59-68.

Medina, M., Sanchez-Tabernero, A., \& Arrese, A. (2016). Contents as product in media markets. In G. F. Lowe \& C. Brown (Eds.). Managing media firms and industries: What's so special about media management?. London: Springer.

Miguens, J., Costa, C., \& Baggio, R. (2008). Social media and tourism destination: Trip advisory case study. Conference Proceeding of the IASK (International Conference on Advances in Tourism Research), Aveiro, Portugal, pp. 194-199.

O'Adewuyi, E., \& Adefem, K. (2016). Behaviour change communication using social media review. International Journal of Communication and Health, 9, 109-116.

Prisgunanto, I. (2016). Komunikasi pemasaran era digital. Jakarta: Insan Cendekia.

Quinn, K. (2018). Cognitive effects of social media use: A case of older adults. Journal of Social Media and Society, 4(7), 1-9.

Rathony, G. (2013). Influence of social media on tourism, especially among students of the University Debrecen. Journal of Applied Studies in Agribusiness and Commerce, 7, 105112.

Rosengren, K. E., Wenner, L. A., \& Palmgreen, P. (eds.) (1985). Media gratifications research: Current perspectives. Beverly Hills: Sage Publishing.

Safko, L. (2010). The social media Bible: Tactics, tools \& strategies for business success (3rd ed.) New Jersey: John Wiley.

Shyle, I., \& Hysi, V. (2015). Social media and its impact on decision making for trip. European Journal of Interdisciplinary Studies, 1(1), 8-15.

Singh, A., \& Duhan, P. (2016). Managing public relations and brand image through social media. Hersey: IGI Global.

Tarakci, H. N., \& Yenicikti, N. T. (2016). Instagram in the context of uses and gratification approach: Selcux University example. European Conference on Social and Behavioural Sciences, Sarajevo, Bosnia and Herzegovina, pp. 411-420.

Ting, H., Ming, W. W. P., \& De Run, E. C. (2015). Belief about the use of Instagram: An exploratory study. International Journal of Business Innovation and Research, 2(2), 1531.

Zivkovic, R., Gajic, J., \& Brdar, I. (2014). The impact of social media on tourism. SINTEZA, Business in Tourism and Hospitality, 758-761. 